\title{
Two strategies for the synthesis of the biologically important ATP analogue Apppl, at a multi-milligram scale
}

\author{
Janne Weisell, Jouko Vepsäläinen and Petri A. Turhanen *
}

\author{
Letter \\ Address: \\ University of Eastern Finland, School of Pharmacy, Biocenter Kuopio, \\ P.O. Box 1627, FIN-70211, Kuopio, Finland \\ Email: \\ Petri A. Turhanen* - petri.turhanen@uef.fi \\ * Corresponding author \\ Keywords: \\ Apppl; ATP analogue; HPLC; purification; synthesis
}

\author{
Beilstein J. Org. Chem. 2015, 11, 2189-2193. \\ doi:10.3762/bjoc.11.237 \\ Received: 17 August 2015 \\ Accepted: 06 November 2015 \\ Published: 13 November 2015 \\ Associate Editor: K. N. Ganesh \\ (c) 2015 Weisell et al; licensee Beilstein-Institut. \\ License and terms: see end of document.
}

\begin{abstract}
Two strategies for the synthesis of the ATP (adenosine triphosphate) analogue ApppI [1-adenosin-5'-yl 3-(3-methylbut-3enyl)triphosphoric acid diester] (1) are described. ApppI is an active metabolite of the mevalonate pathway and thus is of major biological significance. Chemically synthezised ApppI was purified by using triethylammonium bicarbonate as the counter ion in ionpair chromatography and characterized by ${ }^{1} \mathrm{H},{ }^{13} \mathrm{C},{ }^{31} \mathrm{P}$ NMR and MS spectroscopical methods.
\end{abstract}

\section{Findings}

Bisphosphonates (BPs), which are stable analogues of pyrophosphate occurring in cells, have been used for decades for the treatment of many kinds of bone related diseases, with osteoporosis probably being the most well-known indication $[1,2]$. BPs can be separated into two groups: non-nitrogen containing BPs (non-N-BPs) such as etidronate and clodronate, and nitrogen containing BPs (N-BPs) like pamidronate, alendronate and risedronate (Figure 1) [2]. BPs from these two groups have different mechanisms of action in the body. N-BPs, such as alendronate, inhibit the mevalonate pathway (MVP) in cells and promote the formation of ApppI, which has been demonstrated to induce apoptosis in osteoclasts [3]. Furthermore, ApppI has the ability to activate $\mathrm{T}$ cells together with isopentenyl diphosphate (IPP) [4]. ApppI has interesting prop- erties and their clarification might explain many of the biological functions of N-BPs. Unfortunately, these studies are hampered by the very limited availability of ApppI.

There are only few methods described in the literature which can be used in the chemical synthesis of ApppI. One is the method Mönkkönen et al. [3] followed in their synthesis which has been first described by Eggerer and Lynen [5] and another method is the chemical synthesis of ApppI described by Vantourout et al. [6]. According to our earlier experiments following the procedure published by Eggerer and Lynen [5], the yield of the product after isolation was only $1-2 \%$. Vantourout et al. [6] claimed that they could produce ApppI with a yield of $45 \%$ (mass of the product was not reported); 
non-N-BPs

N-BPs<smiles>CC(O)(P(=O)(O)O)P(=O)(O)O</smiles>

etidronate<smiles>O=P(O)(O)C(Cl)(Cl)P(=O)(O)O[Na]</smiles>

clodronate<smiles>NCCC(O)(P(=O)(O)O)P(=O)(O)O[Na]</smiles>

pamidronate<smiles>NCCCC(O)(P(=O)(O)O)P(=O)(O)O</smiles>

alendronate<smiles>O=P(O)(O)C(O)(Cc1cccnc1)P(=O)(O)O</smiles>

risedronate

Figure 1: Examples of non-N-BPs and N-BPs.

they used a procedure adapted from Ryu and Scott [7] but their report did not contain any NMR characterization data, only HPLC and MS data were presented, and these are rather unsatisfactory methods with which to prove the purity of a product. They also stated that there was 5-10\% ADP (adenosine diphosphate) as an impurity in some preparations and that it is possible that there may have been other impurities which could not be detected with HPLC and MS techniques.

The starting point for the research presented in this paper was the urgent need to produce a supply of ApppI for different kinds of biological assays and as a reference compound for mass spectrometric analyses. We have received several requests to synthesize ApppI. Here we report two reasonable methods which can produce ApppI at a multi-milligram scale; one of these syntheses is a novel approach (method A, Scheme 1); the second is based on the method reported by Ryu and Scott [7] which was subsequently adapted by Vantourout et al. [6]; however, we provide full details of the approach (method B, Scheme 1).

In method A, the bis(tetrabutylammonium) salt of ADP was first treated with in situ prepared 3-methylbut-3-en-1-yl (trimethylsilyl) phosphorochloridate (2) (see synthesis route in Scheme 2) followed by deprotection of the silyl group with $\mathrm{MeOH}$ to produce ApppI (1). It needs to be mentioned that the conversion of salt $\mathbf{5}$ into its acid form $\mathbf{6}$ was performed using $\mathrm{HCl}(\mathrm{aq})$, because the more common Dowex $\mathrm{H}^{+}$resin treatment caused an unexpected side-reaction which led us to find a novel powerful tool to perform the organic addition and substitution reactions [8]. In method $B$, the bis(tetrabutylammonium) salt of ATP was treated with isopentenyl tosylate to produce ApppI. The crude products were purified by an ion-pair chromatographical approach, based on the method first reported by Ryu

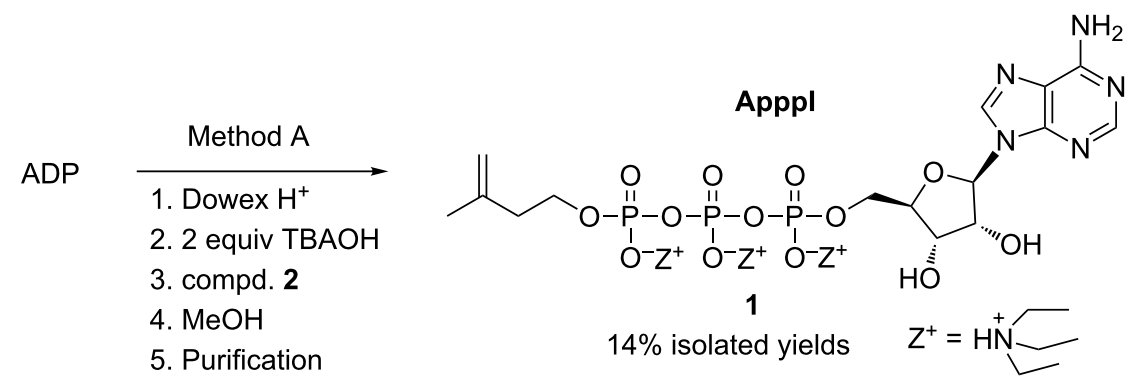

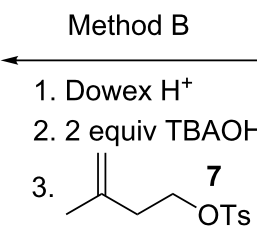

4. Purification

Scheme 1: Synthesis of Apppl (1).

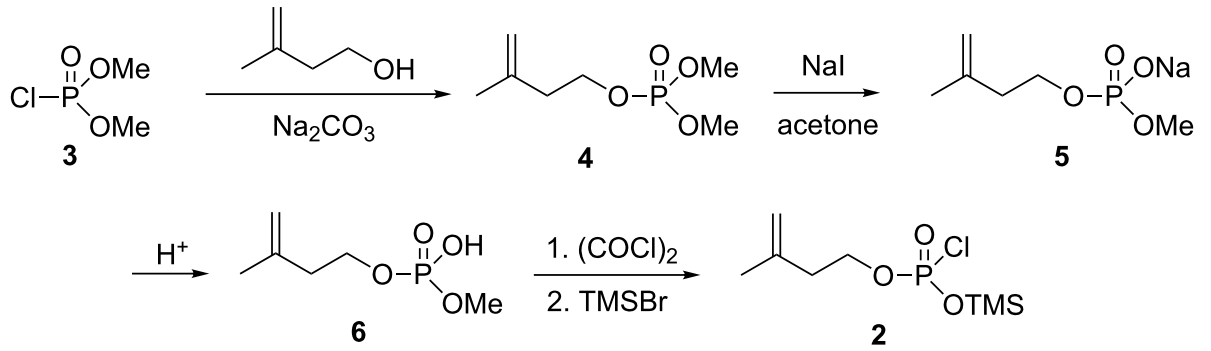


and Scott [7], using triethylammonium bicarbonate (TEAB) as the ion-pair reagent. In both methods, the reaction was performed at near to physiological temperature $\left(35-40{ }^{\circ} \mathrm{C}\right)$. Interestingly, the yield of product 1 after purification was approx. 14\%, irrespective of which method was used (method A or B); these yield amounts are very reasonable for this kind of compound which has two chemically and enzymatically labile $\mathrm{P}-\mathrm{O}-\mathrm{P}$ bonds. In fact, when the temperature was raised slightly, to only approx. $45-50{ }^{\circ} \mathrm{C}$, the yields were lower probably due to the instability of ApppI at the elevated temperature. However, the purified ApppI (1) seems to be stable, since a NMR sample was stored in $\mathrm{D}_{2} \mathrm{O}$ in an NMR tube at room temperature and after approx. 1.5 years' storage, the ${ }^{1} \mathrm{H}$ and ${ }^{31} \mathrm{P}$ NMR spectra were measured and no evidence of degradation was observed according to the spectra, i.e., it can be concluded that purified ApppI tris(triethylammonium) salt is highly stable against chemical hydrolysis at room temperature.

Since Vantourout et al. [6] did not report the amount of tetrabutylammonium used in their synthesis of ApppI, we tested whether mono tetrabutylammonium salts of ADP and ATP could be used as starting materials to produce ApppI (1) following both methods $\mathrm{A}$ and $\mathrm{B}$, respectively, but either very little or no production of ApppI (1) at all could be detected according to the ${ }^{1} \mathrm{H}$ and ${ }^{31} \mathrm{P}$ NMR spectra measured from the crude products. In addition, other strategies for the preparation of ApppI (1) were tested but these methods led to the formation of very complicated mixtures of products.

It remain unclear for us why reasonably reported method(s) to prepare ApppI lack in the literature because methods to prepare ATP analogues have been reported [9-11]. We propose that one of the main reasons for this maybe the sensitivity of the isopentenyl group to addition reactions under mild reaction conditions [8] combined with the sensitivity of the two $\mathrm{P}-\mathrm{O}-\mathrm{P}$ bridges for hydrolysis. These points may explain at least partly the quite low $14 \%$ isolated yields for ApppI we reported in this paper.

\section{Conclusion}

In conclusion, two feasible methods to synthesize the very important metabolite ApppI (1) have been described and for the first time, the methods are described in detail. ApppI is a rather interesting compound which is known to exert several unique biological effects and it is possible that novel properties await discovery. Now we can produce ApppI at a multi-milligram scale which will be important in advancing research into this interesting metabolite.

\section{Experimental}

${ }^{1} \mathrm{H},{ }^{31} \mathrm{P}$ and ${ }^{13} \mathrm{C}$ NMR spectra were recorded on a $500 \mathrm{MHz}$ spectrometer operating at 500.1, 202.5 and $125.8 \mathrm{MHz}$, respect- ively. Dimethyl phosphorochloridate (3) is commercially available. 3-Methyl-3-buten-1-yl dimethyl phosphate (4) can be prepared as reported by Chen and Dale Poulter elsewhere [12]. Commercially available ADP mono sodium salt and ATP disodium salt were converted to the corresponding bis(tetrabutylammonium) salts by rapid treatment with Dowex $\mathrm{H}^{+}$resin and the addition of 2 equiv of $40 \%$ tetrabutylammonium hydroxide in $\mathrm{H}_{2} \mathrm{O}$. The ApppI tris(triethylammonium) salt was converted into the disodium salt by the same method except that $0.1 \mathrm{M} \mathrm{NaOH}$ solution was used (see additional ${ }^{13} \mathrm{C}$ NMR spectrum in Supporting Information File 1). The solvent residual peak was used as a standard for ${ }^{1} \mathrm{H}$ and ${ }^{13} \mathrm{C}$ measurements in $\mathrm{CDCl}_{3}$ and $\mathrm{CD}_{3} \mathrm{OD}$ (7.26 ppm or $77.16 \mathrm{ppm}$ for $\mathrm{CDCl}_{3}$ and $3.31 \mathrm{ppm}$ or $49.00 \mathrm{ppm}$ for $\mathrm{CD}_{3} \mathrm{OD}$, respectively) [13], in $\mathrm{D}_{2} \mathrm{O}$ $4.79 \mathrm{ppm}$ in ${ }^{1} \mathrm{H}$ measurements and trimethylsilylpropionic acid sodium salt (TSP) in ${ }^{13} \mathrm{C}$ measurements $(0.00 \mathrm{ppm})$ and $85 \%$ $\mathrm{H}_{3} \mathrm{PO}_{4}$ was used as an external standard in the ${ }^{31} \mathrm{P}$ measurements. The ${ }^{\mathrm{n}} J_{\mathrm{HP}}$ couplings were calculated from proton spectra and all $J$ values are given in $\mathrm{Hz}$. The ${ }^{\mathrm{n}} J_{\mathrm{CP}}$ couplings were calculated from carbon spectra with the coupling constants given in parenthesis as Hertz. Ion-pair chromatography was performed with a VP10 HPLC system using a Phenomenex Jupiter C18column $(250 \times 10 \mathrm{~mm})$ and with an $\mathrm{MeCN}$ gradient $[0.1 \mathrm{M}$ TEAB (triethylammonium bicarbonate) in $\mathrm{H}_{2} \mathrm{O} / 0-37 \% \mathrm{MeCN}$ gradient for $35 \mathrm{~min}$ ] with a flow rate of $5 \mathrm{~mL} / \mathrm{min}$. The gradient started after $2.5 \mathrm{~min}$ loading of sample into column using $0.1 \mathrm{M}$ TEAB in $\mathrm{H}_{2} \mathrm{O}$. Mass spectra were recorded on a quadrupole time-of-flight mass spectrometer using electrospray ionization (ESI) in the positive ionization mode. The purity of the products was determined from ${ }^{1} \mathrm{H}$ and ${ }^{31} \mathrm{P}$ NMR spectra and was $\geq 95 \%$ unless stated otherwise.

Procedure for the preparation of isopentenyl tosylate (7): 3-Methyl-3-buten-1-ol (770 $\mu \mathrm{L}, 655 \mathrm{mg}, 7.6 \mathrm{mmol})$ was dissolved in dry acetonitrile $(10 \mathrm{~mL})$, distilled pyridine $(610 \mu \mathrm{L}$, $602 \mathrm{mg}, 7.6 \mathrm{mmol})$ and tosyl chloride (1460 mg, $7.7 \mathrm{mmol})$ were added and the reaction mixture was stirred 4 hours at room temperature. The reaction mixture was evaporated to dryness and dissolved in diethyl ether $(20 \mathrm{~mL})$, filtered and then the ether was removed in vacuo. The crude product was purified by silica column chromatography using EtOAc/hexane (5:95) as eluent to give $7(1.22 \mathrm{~g}, 67 \%)$ as a colorless oil. All ${ }^{1} \mathrm{H}$ NMR data were comparable to those reported elsewhere [14]. ${ }^{1} \mathrm{H} \mathrm{NMR}\left(\mathrm{CDCl}_{3}\right) 7.79(\mathrm{~d}, J=8.0,2 \mathrm{H}), 7.34(\mathrm{~d}, J=8.0,2 \mathrm{H})$, $4.79(\mathrm{~s}, 1 \mathrm{H}), 4.67(\mathrm{~s}, 1 \mathrm{H}), 4.13(\mathrm{t}, J=7.0,2 \mathrm{H}), 2.45(\mathrm{~s}, 3 \mathrm{H})$, $2.35(\mathrm{t}, J=6.8,2 \mathrm{H}), 1.66(\mathrm{~s}, 3 \mathrm{H})$.

Procedure for the preparation of 3-methyl-3-buten-1-yl dimethyl phosphate (4): Dimethyl phosphorochloridate 3 (2.68 g, $2.0 \mathrm{~mL}, 18.5 \mathrm{mmol}$ ) was dissolved in dry acetonitrile (15 mL), dry $\mathrm{Na}_{2} \mathrm{CO}_{3}(2.15 \mathrm{~g}, 20.3 \mathrm{mmol})$ and 3-methyl-3- 
buten-1-ol (2.25 mL, $1.91 \mathrm{~g}, 22.2 \mathrm{mmol})$ were added and the reaction mixture was stirred for 7 days at $50{ }^{\circ} \mathrm{C}$. The reaction mixture was evaporated to dryness and dissolved in diethyl ether $(20 \mathrm{~mL})$, filtered and volatile compounds were removed in vacuo. The product 4 (822 $\mathrm{mg}, 23 \%)$ was present as a colorless oil. All NMR data were comparable to those reported elsewhere (except $-\mathrm{OCH}_{3}$ signals which was wrongly interpreted to be two singlets although those protons are coupled to phosphorus) [12]. ${ }^{1} \mathrm{H}$ NMR $\left(\mathrm{CDCl}_{3}\right) 4.84(\mathrm{~s}, 1 \mathrm{H}), 4.77(\mathrm{~s}, 1 \mathrm{H}), 4.16$ (vq, $2 \mathrm{H}), 3.76\left(\mathrm{~d},{ }^{3} J_{\mathrm{HP}}=11.5,6 \mathrm{H}\right), 2.41(\mathrm{t}, J=6.5,2 \mathrm{H}), 1.77$ (s, 3H); ${ }^{31} \mathrm{P} \mathrm{NMR}\left(\mathrm{CDCl}_{3}\right) \delta 1.97$.

Procedure for the preparation of methyl (3-methylbut-3-en1-yl) hydrogen phosphate (6): Compound 4 (817 mg, $4.2 \mathrm{mmol})$ was dissolved in dry acetone $(15 \mathrm{~mL})$, dried NaI $(567 \mathrm{mg}, 3.8 \mathrm{mmol})$ was added and the reaction mixture was stirred for $24 \mathrm{~h}$ at $60{ }^{\circ} \mathrm{C}$ before it was evaporated to dryness. The residue washed twice with diethyl ether and dried in vacuo yielding compound 5 as a yellow solid (734 mg, 96\%). Compound $5(375 \mathrm{mg}, 1.86 \mathrm{mmol})$ was suspended in acetone $(6 \mathrm{~mL})$ and $6 \mathrm{M} \mathrm{HCl}(310 \mu \mathrm{L}, 1$ equiv) was added and reaction mixture stirred for $5 \mathrm{~min}$. The reaction mixture was filtered and the filtrate evaporated to dryness. The crude product was purified by silica column chromatography using EtOAc/MeOH (3:7) as the eluent producing 6 (249 $\mathrm{mg}, 75 \%)$ as a viscous oil. ${ }^{1} \mathrm{H}$ NMR $\left(\mathrm{CD}_{3} \mathrm{OD}\right) 4.78(\mathrm{~s}, 1 \mathrm{H}), 4.76(\mathrm{~s}, 1 \mathrm{H}), 3.95(\mathrm{vq}, 2 \mathrm{H}), 3.57(\mathrm{~d}$, $\left.{ }^{3} J_{\mathrm{HP}}=11.0,3 \mathrm{H}\right), 2.35(\mathrm{t}, J=7.0,2 \mathrm{H}), 1.77(\mathrm{~s}, 3 \mathrm{H}) ;{ }^{31} \mathrm{P} \mathrm{NMR}$ $\left(\mathrm{CD}_{3} \mathrm{OD}\right) \delta 4.67 ;{ }^{13} \mathrm{C} \mathrm{NMR}\left(\mathrm{CD}_{3} \mathrm{OD}\right) \delta 143.7,112.3,65.1$ (d, $\left.{ }^{2} J_{\mathrm{CP}}=6.3\right), 53.0\left(\mathrm{~d},{ }^{2} J_{\mathrm{CP}}=6.3\right), 39.8\left(\mathrm{~d},{ }^{3} J_{\mathrm{CP}}=7.5\right)$.

Procedure for the preparation of crude 1-adenosin-5'-yl 3-(3-methylbut-3-enyl) triphosphoric diester (ApppI) (1), Method A: Oxalyl chloride (180 mg, $120 \mu \mathrm{L}, 1.42 \mathrm{mmol}$ ) was dissolved in dry DCM (2 mL), one drop of DMF was added and the reaction mixture stirred at $45{ }^{\circ} \mathrm{C}$. Compound 6 (248 mg, $1.38 \mathrm{mmol}$ ) was dissolved in dry dioxane $(3 \mathrm{~mL})$ and added in portions to the reaction mixture. After the additions were completed, the reaction mixture was stirred for $1 \mathrm{~h}$ at $45{ }^{\circ} \mathrm{C}$ before the reaction mixture was cooled to room temperature and trimethylsilyl bromide ( $325 \mathrm{mg}, 280 \mu \mathrm{L}, 2.12 \mathrm{mmol}$ ) was added and the reaction mixture stirred overnight at room temperature. The reaction mixture was evaporated to dryness and dissolved in dry acetonitrile $(3 \mathrm{~mL})$ and added in portions to a solution of acetonitrile $(4 \mathrm{~mL})$ in which ADP bis(tetrabutylammonium) salt $(1.25 \mathrm{~g}, 1.38 \mathrm{mmol})$ was dissolved. After the addition was completed, the reaction mixture was stirred for $24 \mathrm{~h}$ at $40{ }^{\circ} \mathrm{C}$ before it was evaporated to dryness and the residue dissolved in $\mathrm{MeOH}(8 \mathrm{~mL})$ and stirred overnight at room temperature. The reaction mixture was evaporated to dryness and crude product 1 $(1.42 \mathrm{~g})$ was obtained as hygroscopic solid. The HPLC purification run was performed ( $29 \mathrm{mg}$ loaded amount) and compound
$1(3.8 \mathrm{mg}, 13.5 \%)$ was obtained as a white hygroscopic solid after evaporation of appropriate fractions in vacuo. Method B: ATP bis(tetrabutylammonium) salt (187 mg, $0.189 \mathrm{mmol}$ ) was dissolved in dry acetonitrile $(1 \mathrm{~mL})$ and isopentenyl tosylate 7 (48 $\mathrm{mg}, 0.200 \mathrm{mmol}$ ) was added and the reaction mixture stirred for $24 \mathrm{~h}$ at $40^{\circ} \mathrm{C}$ before the reaction mixture was evaporated to dryness and the residue washed with diethyl ether $(3 \mathrm{~mL})$ and dried in vacuo. The crude product $\mathbf{1}(204 \mathrm{mg}$ ) was obtained as a hygroscopic solid. Two HPLC purification runs were performed (20 $\mathrm{mg}$ and $24 \mathrm{mg}$ loaded amounts) and compound $\mathbf{1}$ (tot. $4.8 \mathrm{mg}, 14.2 \%$ ) was obtained as a white hygroscopic solid after evaporation of the appropriate fractions in vacuo.

1-Adenosin-5'-yl 3-(3-methylbut-3-enyl) triphosphoric diester (ApppI) tris(triethylammonium) salt (1): White solid (very hygroscopic). ${ }^{1} \mathrm{H}$ NMR $\left(\mathrm{D}_{2} \mathrm{O}\right) \delta 8.59(\mathrm{~s}, 1 \mathrm{H}), 8.32(\mathrm{~s}, 1 \mathrm{H})$, $6.18(\mathrm{~d}, J=6.0,1 \mathrm{H}), 4.62-4.59(\mathrm{~m}, 1 \mathrm{H}), 4.45-4.41(\mathrm{~m}, 1 \mathrm{H})$, $4.34-4.23(\mathrm{~m}, 2 \mathrm{H}), 4.08-4.00(\mathrm{~m}, 2 \mathrm{H}), 3.24(\mathrm{q}, J=7.0,16 \mathrm{H}$, from triethylammonium salt), $2.30(\mathrm{t}, J=6.5,2 \mathrm{H}), 1.69(\mathrm{~s}, 3 \mathrm{H})$, 1.31 (t, $J=7.5,24 \mathrm{H}$, from triethylammonium salt). $\mathrm{C}=\mathrm{CH}_{2}$ signals and one "sugar" proton signal under HDO-line at 4.8 . ${ }^{13} \mathrm{C}$ NMR $\left(\mathrm{D}_{2} \mathrm{O}\right) \delta 158.5,155.7,152.1,146.2,142.8,121.6$, $114.2,89.6,86.9\left(\mathrm{~d},{ }^{2} J_{\mathrm{CP}}=9.3\right), 77.2,73.3,68.1\left(\mathrm{~d},{ }^{3} J_{\mathrm{CP}}=\right.$ 5.0), $67.6\left(\mathrm{~d},{ }^{2} J_{\mathrm{CP}}=6.1\right), 49.6,40.6\left(\mathrm{~d},{ }^{3} J_{\mathrm{CP}}=7.3\right) ;{ }^{31} \mathrm{P} \mathrm{NMR}$ $\left(\mathrm{D}_{2} \mathrm{O}\right) \delta-10.36 \mathrm{~d}\left({ }^{2} J_{\mathrm{PP}}=18.2\right),-10.74 \mathrm{~d}\left({ }^{2} J_{\mathrm{PP}}=18.2\right),-22.54$ $\mathrm{t}\left({ }^{2} J_{\mathrm{PP}}=18.2\right) ; \mathrm{MS}\left(\mathrm{ESI}^{+}\right):[\mathrm{M}-\mathrm{H}]^{-} \mathrm{calcd}$. for $\mathrm{C}_{15} \mathrm{H}_{23} \mathrm{~N}_{5} \mathrm{O}_{13} \mathrm{P}_{3}$, 574.0505; found: 574.0517.

\section{Supporting Information}

\section{Supporting Information File 1}

${ }^{1} \mathrm{H},{ }^{13} \mathrm{C}$ and ${ }^{31} \mathrm{P}$ NMR spectra for ApppI (1) and typical example of HPLC chromatogram of ApppI purification. [http://www.beilstein-journals.org/bjoc/content/ supplementary/1860-5397-11-237-S1.pdf]

\section{Acknowledgements}

Research has been supported by strategic funding of the University of Eastern Finland. The authors would like to thank Mrs. Maritta Salminkoski for her expert technical assistance.

\section{References}

1. Graham, R.; Russell, G. Bone 2011, 49, 2-19. doi:10.1016/j.bone.2011.04.022

2. Ebetino, F. H.; Hogan, A.-M. L.; Sun, S.; Tsoumpra, M. K.; Duan, X.; Triffitt, J. T.; Kwaasi, A. A.; Dunford, J. E.; Barnett, B. L.; Oppermann, U.; Lundy, M. W.; Boyde, A.; Kashemirov, B. A.; McKenna, C. E.; Russell, R. G. G. Bone 2011, 49, 20-33. doi:10.1016/j.bone.2011.03.774 
3. Mönkkönen, H.; Auriola, S.; Lehenkari, P.; Kellinsalmi, M.; Hassinen, I. E.; Vepsäläinen, J.; Mönkkönen, J. Br. J. Pharmacol. 2006, 147, 437-445. doi:10.1038/sj.bjp.0706628

4. Vantourout, P.; Hayday, A. Nat. Rev. Immunol. 2013, 13, 88-100. doi:10.1038/nri3384

5. Eggerer, H.; Lynen, F. Justus Liebigs Ann. Chem. 1960, 630, 58-70. doi:10.1002/jlac.19606300109

6. Vantourout, P.; Mookerjee-Basu, J.; Rolland, C.; Pont, F.; Martin, H.; Davrinche, C.; Martinez, L. O.; Perret, B.; Collet, X.; Périgaud, C.; Peyrottes, S.; Champagne, E. J. Immunol. 2009, 183, 3848-3857. doi:10.4049/jimmunol.0901085

7. Ryu, Y.; Scott, A. I. Org. Lett. 2003, 5, 4713-4715. doi:10.1021/ol035880b

8. Turhanen, P. A.; Vepsäläinen, J. J. RSC Adv. 2015, 5, 26218-26222. doi:10.1039/C4RA17321J

9. Hacker, S. M.; Mex, M.; Marx, A. J. Org. Chem. 2012, 77, 10450-10454. doi:10.1021/jo301923p

10. Lee, S. E.; Elphick, L. M.; Anderson, A. A.; Bonnac, L.; Child, E. S.; Mann, D. J.; Gouverneur, V. Bioorg. Med. Chem. Lett. 2009, 19, 3804-3807. doi:10.1016/j.bmcl.2009.04.028

11. Sood, A.; Kumar, S.; Nampalli, S.; Nelson, J. R.; Macklin, J.; Fuller, C. W. J. Am. Chem. Soc. 2005, 127, 2394-2395. doi:10.1021/ja043595x

12. Chen, M.; Poulter, C. D. Biochemistry 2010, 49, 207-217. doi:10.1021/bi9017957

13. Gottlieb, H. E.; Kotlyar, V.; Nudelman, A. J. Org. Chem. 1997, 62, 7512-7515. doi:10.1021/jo971176v

14. Kao, C.-I.; Kittleman, W.; Zhang, H.; Seto, H.; Liu, H.-w. Org. Lett. 2005, 7, 5677-5680. doi:10.1021/ol0524050

\section{License and Terms}

This is an Open Access article under the terms of the Creative Commons Attribution License

(http://creativecommons.org/licenses/by/2.0), which permits unrestricted use, distribution, and reproduction in any medium, provided the original work is properly cited.

The license is subject to the Beilstein Journal of Organic Chemistry terms and conditions:

(http://www.beilstein-journals.org/bjoc)

The definitive version of this article is the electronic one which can be found at: doi:10.3762/bjoc. 11.237 